\footnotetext{
${ }^{1)}$ Institute of Animal Production in the Tropics and Subtropics, University of Hohenheim, Germany

$\left.{ }^{2}\right)$ Research Centre for Animal Production and Technology, University of Göttingen, Germany

3) Organic Agricultural Sciences, FB 11, University of Kassel, Germany
}

\author{
PERA HEROLD ${ }^{1)}$, HINRICH SNELL ${ }^{2)}$ and EZZAT S. TAWFIK ${ }^{3)}$
}

\title{
Growth, carcass and meat quality parameters of purebred and crossbred goat kids in extensive pasture
}

\begin{abstract}
Goats are more and more used as shrub-fighters in landscape conservation. Important traits for the extensive production system are vitality and robustness but also acceptable meat production of kids during the grazing period. To investigate possible selection traits for "landscape conservation suitability", 35 kids were investigated for vitality parameters directly after birth whereas all-in 65 kids were investigated for performance traits under extensive grazing conditions. Birth weight as a parameter for vitality and survivability of kids was significantly influenced by sex, genotype and age of doe. Besides rectal temperature 3 hours p.p., other factors regarded as possible vitality parameters were not influenced by birth weight. Birth weight had a significant influence on daily weight gain during the extensive period; kids with higher birth weight showed slightly better weight gain. Birth weight had also a significant effect on some carcass parts, indicating that higher birth weight implies a high probability of a better carcass performance especially in some valuable parts. Still, the effect of the genotype on carcass performance was considerably higher than any other investigated effect. As a result of the present study, there are indications that birth weight can be taken as a parameter for kids' vitality. Also, it is indicated that goats of Cashmere type as fibre animals are not appropriate for landscape management whereas crossbred animals with a meat, dairy and fibre component in their genotype showed to be a vital animal with acceptable efficiency also in harsh conditions and with an average meat and carcass performance.
\end{abstract}

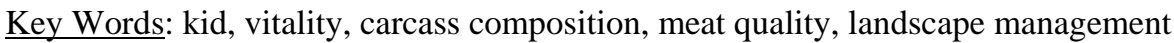

\section{Zusammenfassung}

Titel der Arbeit: Wachstum, Schlachtleistung und Fleischqualität von Ziegenkitzen aus Rein- und Kreuzungszucht bei extensiver Weidehaltung

In der Landschaftspflege werden zunehmend Ziegen eingesetzt. Wichtige Merkmale sind dabei Vitalität und Robustheit, aber auch ein angemessener Fleischansatz der Ziegenkitze während der Weideperiode. An 35 Ziegenkitzen wurden direkt nach der Geburt verschiedene Vitalitätsparameter gemessen. Insgesamt wurden Leistungsparameter an 65 Kitzen untersucht, um mögliche Selektionskriterien für die Eignung zum Landschaftspflegeeinsatz identifizieren zu können. Dabei wurde das Geburtsgewicht als Merkmal für die Vitalität und Überlebensfähigkeit signifikant von Geschlecht, Genotyp und Alter der Mutter beeinflusst. Bei den weiter untersuchten Vitalitätsparametern wirkte sich das Geburtsgewicht nur auf die Rektaltemperatur signifikant aus. Ein signifikanter Einfluss des Geburtsgewichts auf die Gewichtszunahme während der Landschaftspflegephase konnte nachgewiesen werden, Kitze mit höherem Geburtsgewicht zeigten eine bessere Gewichtszunahme. Ebenfalls konnte ein signifikanter Einfluss des Geburtsgewichts auf verschiedene Schlachtkörpermerkmale nachgewiesen werden. Hieraus lässt sich ableiten, dass ein höheres Geburtsgewicht eine bessere Schlachtkörperleistung und insbesondere eine bessere Ausprägung wertvoller Teilstücke erwarten lässt. Allerdings war der Einfluss des Genotyps auf die Schlachtkörperleistung wesentlich höher als der aller anderen untersuchten Effekte. Insgesamt lässt sich festhalten, dass das Geburtsgewicht als ein Merkmal für die Vitalität von Ziegenkitzen herangezogen werden kann. Außerdem zeigte sich, dass Faserziegen im Kaschmir-Typ nicht für die extensiven Bedingungen in der Landschaftspflege geeignet sind, während Kreuzungstiere aus Fleisch-, Milch- und Faser-Rassen sich als sehr vitale Tiere erwiesen, die eine akzeptable Fleischleistung und -qualität auch unter sehr extensiven Bedingungen erbringen können. 


\section{Introduction}

In Germany and other European countries, grazing with large and small ruminants is getting increasingly important in nature conservation (SEIBERT et al., 2004). The changes in the appearance of landscape, especially an increase in shrubs and trees and a decline in open meadows and fields, lead to the demand by the public to preserve cultural landscapes as biotopes. If grazing systems are used for landscape conservation, goats are first choice as shrub and tree "fighters". Because landscape conservation is mostly practised as a sideline, it should be a low-cost-low-labour enterprise. In goat grazing, important traits for this extensive production system are the vitality and robustness of the animals (HAUMANN, 2000). Besides, the animals should produce an acceptable carcass during an extensive grazing period (HAUMANN, 1999; HAUMANN, 2000). The aim of this study was to investigate possible traits for "landscape conservation suitability" in goat kids. Emphasis was put on vitality of kids and carcass and meat parameters.

\section{Animals, Materials and Methods}

Study location and management

The experimental kids were of crossbred Cashmere x (Boer x German Fawn) genotype and of "purebred" Cashmere genotype in the New Zealand type. The kids were offspring of the goat herd managed at the University of Kassel/Witzenhausen experimental farm Neu-Eichenberg-Dorf, Hesse, Germany. The goats were kept in a free run stable with paddock. During summer, the herd was used for landscape conservation grazing in different locations a few kilometres away from Neu Eichenberg.

\section{Vitality parameters}

In 1999, vitality parameters of 35 kids were investigated, 23 of crossbred genotype and 12 of purebred genotype. They were all born in-between four days and all births were observed by the same person. All births took place between 8.00 am and $3.30 \mathrm{pm}$. Parameters were the time period until first standing (min p.p.), time period until first colostrum intake (min p.p.), birth weight (kg, 3 hours p.p.) and rectal temperature $\left({ }^{\circ} \mathrm{C}\right.$, 3 hours p.p.). The time period until first standing was regarded as the period of time between the full coming out of the womb and the first successful longer standing on four legs of the kid. Normally, it takes the kids some time whereas they try standing unsuccessfully because they are not able to keep in balance. The time period until first colostrum intake was measured as the time spent from full coming out to first real suckling on the udder. Suckling was classified „successful” if the kid took the teat for some time in its mouth, suckling and swallowing could definitely be registered and the characteristic tail waggling was performed. Three hours p.p. the kids were weighed on electronic scales and the rectal temperature was measured.

\section{Weight development}

For the evaluation of the goat kids' performance in extensive husbandry conditions, 52 crossbreds and 13 purebreds were further investigated during the following month. These animals included the 35 kids of the previous study on vitality parameters at birth; for the other 30 kids' only birth weight had been recorded. Phase 1 includes time period directly after birth (in the stable) and the first month out on pasture (100 \pm 3 
days). Phase 2 includes the grazing of kids and their does on conservation sites and some weeks on pasture (97 \pm 7 days). The conservation areas were marginal infertile grasslands with a shrub encroachment of 40 to $60 \%$; additional feeding besides ad libitum water supply was prohibited by nature conservation law.

\section{Meat and carcass performance}

To investigate the meat performance, condition scoring for 65 kids was done by four people at an age of $192.2 \pm 6.8$ days according to a modified DeutscheLandwirtschafts-Gesellschaft (DLG)-scheme for meat condition scoring in sheep (SCHÖN, 1961). Finally, 53 kids were slaughtered at an age of $197.5 \pm 4.7$ days. Carcasses were judged for meatiness and fat cover according to the commercial standards for sheep carcasses (EWG 2137/92 and EWG 461/93) as described by SNELL (1996).

The carcasses were dissected according to the DLG-scheme for sheep (SCHEPER and SCHOLZ, 1985) and all parts were weighed. The cut at longissimus muscle was photographed between the $11^{\text {th }}$ and $12^{\text {th }}$ rip with a digital camera. The interpretation of the photographs was done with Adobe Photoshop: the muscle area was plotted and the surface area of the marked area calculated. The meat:fat-relation could not be measured because the fat was nearly not visible. The $\mathrm{pH}$-value in longissimus muscle was measured 45 min. and 24 hours p.m. and conductivity 24 hours p.m. Meat colour was measured with a Chromameter CR-200b (Minolta, Japan) detecting lightness ( $\left.\mathrm{L}^{*}\right)$, red index $\left(\mathrm{a}^{*}\right)$ and yellow index $\left(\mathrm{b}^{*}\right)$. Also, back length, gigot length and gigot circumference were measured.

Statistical analysis

Statistical analysis was done for the vitality parameters, the growing period and the slaughter performance, using a generalized linear model with proc GLM in SAS (SAS Inst. Inc., Cary, NC, USA). All categorical data (meat condition scoring, carcass condition scoring) was analysed with a threshold model (MCCULLAGH, 1980; MCCULLAGH and NELDER, 1989; PIEPHO, 1997). For that, the SAS-macro presented by PIEPHO (1998) for the estimation of model parameters according to KEEN and ENGEL (1997) was used.

Independent factors of the analysis were genotype, age of doe, birth type and sex. Birth weight as vitality parameter was used as linear regression coefficient in all models besides the analysis of birth weight itself and besides the analysis for categorical data.

For the analysis of birth weight the model

$$
\begin{aligned}
& y_{i j k}=\mu+\operatorname{Sex}_{i}+G_{j}+A_{G M}+e_{i j k} \text { was used } \\
& \text { with } \mathrm{y}_{\mathrm{ijk}}=\text { birth weight of } \mathrm{ijk}{ }^{\text {th }} \text { kid, } \\
& \mu \quad=\text { overall mean, } \\
& \text { Sex }_{\mathrm{i}} \quad=\mathrm{i}^{\text {th }} \text { sex of kid (i: } 1=\text { female, } 2=\text { male), } \\
& \mathrm{GT}_{\mathrm{j}} \quad=\mathrm{j}^{\text {th }} \text { genotype of kid (j: 1, 2), } \\
& \mathrm{AGM}_{\mathrm{k}}=\mathrm{k}^{\text {th }} \text { age of doe at kidding (k: 2, 3, } 4 \text { years), } \\
& \mathrm{e}_{\mathrm{ijk}} \quad=\text { residual. }
\end{aligned}
$$


The model for other vitality parameters was

$$
\begin{aligned}
& \mathrm{y}_{\mathrm{ijk}}=\mu+\mathrm{Sex}_{\mathrm{i}}+\mathrm{GT}_{\mathrm{j}}+\mathrm{bBW}_{\mathrm{k}}+\mathrm{e}_{\mathrm{ijk}} \\
& \text { with } \mathrm{y}_{\mathrm{ijk}} \quad=\text { vitality parameter of } \mathrm{ij} \mathrm{k}^{\text {th }} \mathrm{kid} \text {, } \\
& \mu \quad=\text { overall mean, } \\
& \left.\operatorname{Sex}_{\mathrm{i}} \quad=\mathrm{i}^{\text {th }} \text { sex of kid (i: } 1,2\right) \text {, } \\
& \mathrm{GT}_{\mathrm{j}} \quad=\mathrm{j}^{\text {th }} \text { genotype of kid }(\mathrm{j}: 1,2) \text {, } \\
& \mathrm{bBW}_{\mathrm{k}}=\text { linear regression coefficient on the average birth weight of the kid } \\
& \text { within all kids, } \\
& \mathrm{e}_{\mathrm{ijk}}=\text { residual. }
\end{aligned}
$$

The model used for analysing daily gain of weight was

$$
\begin{aligned}
& \mathrm{y}_{\mathrm{ij}}=\mu+\mathrm{GT}_{\mathrm{i}}+\mathrm{bBW}_{\mathrm{j}}+\mathrm{e}_{\mathrm{ij}} \\
& \text { with } \mathrm{y}_{\mathrm{ij}} \quad=\text { daily gain of weight Phase } 1 \text { resp. 2, } \\
& \mu \quad=\text { overall mean, } \\
& \left.\mathrm{GT}_{\mathrm{i}} \quad=\mathrm{i}^{\text {th }} \text { genotype of kid (i: } 1,2\right) \text {, } \\
& \mathrm{bBW}_{\mathrm{j}}=\text { linear regression coefficient on the average birth weight of the kid } \\
& \text { within all kids, } \\
& \mathrm{e}_{\mathrm{ij}} \quad=\text { residual. }
\end{aligned}
$$

The model used for analysing carcass and meat quality parameters was

$$
\begin{aligned}
& \mathrm{y}_{\mathrm{ijkl}}=\mu+\mathrm{GT}_{\mathrm{i}}++\operatorname{Sex}_{\mathrm{j}}+\mathrm{BT}_{\mathrm{k}}+\left(\mathrm{GT}^{*} \mathrm{BT}\right)_{\mathrm{ik}}+\mathrm{bBW}_{\mathrm{ijkl}}+\mathrm{e}_{\mathrm{ijkl}} \\
& \text { with } \mathrm{y}_{\mathrm{ijkl}} \quad=\text { carcass resp. meat quality, } \\
& \mu \quad=\text { overall mean, } \\
& \left.\mathrm{GT}_{\mathrm{i}} \quad=\mathrm{i}^{\text {th }} \text { genotype of kid (i: } 1,2\right) \text {, } \\
& \operatorname{Sex}_{\mathrm{j}} \quad=\mathrm{j}^{\text {th }} \text { sex of kid }(\mathrm{j}: 1,2) \text {, } \\
& \mathrm{BT}_{\mathrm{k}} \quad=\mathrm{k}^{\text {th }} \text { birth type of kid }(\mathrm{k}: 1,2) \text {, } \\
& \left(\mathrm{GT}^{*} \mathrm{BT}\right)_{\mathrm{ik}}=\mathrm{ik}^{\text {th }} \text { interaction of genotype and birth type, } \\
& \mathrm{bBW}_{\mathrm{ijkl}}=\text { linear regression coefficient on the average birth weight of the kid } \\
& \text { within all kids, } \\
& \mathrm{e}_{\mathrm{ijkl}} \quad=\text { residual. }
\end{aligned}
$$

The model used for meat condition scoring and carcass scoring was

$$
\begin{aligned}
\mathrm{y}_{\mathrm{ij}}=\mu+\mathrm{GT}_{\mathrm{i}}+\mathrm{Sex}_{\mathrm{j}} & +\mathrm{e}_{\mathrm{ij}} \\
\text { with } \mathrm{y}_{\mathrm{ij}} & =\text { meat condition resp. carcass score, } \\
\mu & =\text { overall mean, } \\
\mathrm{GT}_{\mathrm{i}} & =\mathrm{i}^{\text {th }} \text { genotype of kid }(\mathrm{i}: 1,2), \\
\mathrm{Sex}_{\mathrm{j}} & =\mathrm{j}^{\text {th }} \text { sex of kid }(\mathrm{j}: 1,2), \\
\mathrm{e}_{\mathrm{ij}} & =\text { residual. }
\end{aligned}
$$

For every trait the F-value was calculated and tested for significance. Means with Fvalues on a significance level of $\mathrm{p}<0.05$ were tested with the procedure p.diff for significant differences.

\section{Results}

The birth weight of the kids was significantly influenced by sex, genotype and age of doe (Tab. 1). 
The genotype had an influence on time span from birth to first suckling (Tab. 2). Rectal body temperature three hours p.p. was significantly influenced by sex (Tab. 2) and birth weight.

Table 1

Effect of sex, genotype and age of doe on birth weight $(n=35)$ (Einfluss von Geschlecht, Genotyp und Alter der Mutter auf das Geburtsgewicht $(\mathrm{n}=35))$

\begin{tabular}{llll}
\hline \multirow{2}{*}{ Effect } & & \multicolumn{2}{c}{ Birth weight (kg) } \\
\hline Sex & Female & LSM & 0.09 \\
& Male & $2.45^{\mathrm{a}}$ & 0.09 \\
Genotype & Crossbred & $2.84^{\mathrm{b}}$ & 0.07 \\
& Purebred & $2.82^{\mathrm{a}}$ & 0.11 \\
Age of doe (years) & 2 & $2.47^{\mathrm{b}}$ & 0.16 \\
& 3 & $2.54^{\mathrm{ab}}$ & 0.09 \\
\hline
\end{tabular}

Means of the same effect with different letters differ significantly $(\mathrm{p}<0.05)$.

Table 2

Effect of sex and genotype on the time span from birth to first standing resp. suckling and rectal body temperature 3 hours p.p. $(n=35)$ (Einfluss von Geschlecht und Genotyp auf die Zeitspanne bis zum ersten Stehen bzw. Saugen und auf die Rektaltemperatur 3 Std. p.p. $(n=35))$

\begin{tabular}{|c|c|c|c|c|c|c|c|}
\hline \multirow[b]{2}{*}{ Effect } & & \multicolumn{2}{|c|}{$\begin{array}{l}\text { Time span until first } \\
\text { standing (min) }\end{array}$} & \multicolumn{2}{|c|}{$\begin{array}{l}\text { Time span until first } \\
\text { suckling (min) }\end{array}$} & \multicolumn{2}{|c|}{ Body temperature $\left({ }^{\circ} \mathrm{C}\right)$} \\
\hline & & LSM & SE & LSM & SE & LSM & SE \\
\hline \multirow{2}{*}{ Sex } & Female & 19.09 & 2.38 & 50.39 & 6.98 & $39.17^{\mathrm{a}}$ & 0.07 \\
\hline & Male & 19.41 & 2.05 & 43.30 & 6.00 & $39.47^{\mathrm{b}}$ & 0.06 \\
\hline \multirow{2}{*}{ Genotype } & Crossbred & 18.59 & 1.78 & $36.59^{\mathrm{a}}$ & 5.22 & 39.40 & 0.06 \\
\hline & Purebred & 19.91 & 2.59 & $57.10^{\mathrm{b}}$ & 7.58 & 39.24 & 0.08 \\
\hline
\end{tabular}

Means of the same effect with different letters for each trait differ significantly $(\mathrm{p}<0.05)$.

The daily gain of weight of the kids was calculated for two different phases. Genotype had an influence on the weight gain in both phases (Tab. 3). Birth weight had no influence on daily weight gain in phase 1 but on weight gain in phase 2 .

Table 3

Effect of genotype on daily gain of weight $(n=65)$ (Einfluss des Genotyps auf die täglichen Zunahmen $(n=65))$

\begin{tabular}{|c|c|c|c|c|}
\hline \multirow[b]{2}{*}{ Genotype } & \multicolumn{2}{|c|}{$\begin{array}{l}\text { Daily gain of weight }(\mathrm{kg} / \mathrm{d}) \\
\text { Phase } 1\end{array}$} & \multicolumn{2}{|c|}{ Daily gain of weight $(\mathrm{kg} / \mathrm{d})$} \\
\hline & LSM & SE & LSM & SE \\
\hline Crossbred & $0.139^{\mathrm{a}}$ & 0.005 & $0.076^{\mathrm{a}}$ & 0.004 \\
\hline Purebred & $0.084^{\mathrm{b}}$ & 0.007 & $0.044^{\mathrm{b}}$ & 0.006 \\
\hline
\end{tabular}

Means with different letters for each trait differ significantly $(\mathrm{p}<0.05)$.

Table 4

Effect of genotype on meat condition scoring $(n=65)$ (Einfluss des Genotyps auf die Ergebnisse der Lebendbeurteilung $(n=65))$

\begin{tabular}{|c|c|c|c|c|c|c|c|c|c|c|}
\hline \multirow[b]{2}{*}{ Genotype } & \multicolumn{2}{|c|}{$\begin{array}{l}\text { Overall } \\
\text { Score }^{1}\end{array}$} & \multicolumn{2}{|c|}{ Fat cover $^{2}$} & \multicolumn{2}{|c|}{$\begin{array}{l}\text { Meatiness, } \\
\text { forequarter }^{1}\end{array}$} & \multicolumn{2}{|c|}{$\begin{array}{l}\text { Meatiness, } \\
\text { back }^{1}\end{array}$} & \multicolumn{2}{|c|}{$\begin{array}{l}\text { Meatiness, } \\
\text { hindquarter }^{1}\end{array}$} \\
\hline & $\bar{x}$ & SD & $\bar{x}$ & $\mathrm{SD}$ & $\bar{x}$ & SD & $\overline{\mathrm{X}}$ & SD & $\overline{\mathrm{x}}$ & SD \\
\hline Crossbred & $2.9^{\mathrm{a}}$ & 0.6 & 2.4 & 0.5 & 2.4 & 0.5 & 2.8 & 0.6 & 2.6 & 0.6 \\
\hline Purebred & $2.3^{\mathrm{b}}$ & 0.5 & 2.1 & 0.4 & 2.0 & 0.4 & 2.2 & 0.4 & 2.1 & 0.4 \\
\hline
\end{tabular}

Means with different letters for each trait differ significantly $(\mathrm{p}<0.05)$.

${ }^{1}$ Grades from 1 (bad) to 5 (very good)

${ }^{2}$ Grades from 1 (no fat) to 5 (very fat)

For meat condition scoring of the live animals (Tab. 4), the genotype had a significant impact on the overall impression. Overall, crossbreds got better scores than purebreds. This was also the case for carcass scoring (Tab. 5): Crossbreds got significantly better 
scores for meatiness but there were no differences in fat cover between crossbreds and purebreds.

Table 5

Effect of genotype on carcass scoring $(n=55)$ (Einfluss des Genotyps auf die Schlachtkörperbewertung $(n=$ 55))

\begin{tabular}{|c|c|c|c|c|c|c|}
\hline Genotype & $\bar{x}$ & $\begin{array}{c}\text { Meatiness }^{1} \\
\text { SD }\end{array}$ & $\bar{x}$ & $\begin{array}{c}\text { Fat cover, inside }{ }^{2} \\
\text { SD }\end{array}$ & $\bar{x}$ & $\begin{array}{c}\text { Fat cover, outside } \\
\text { SD }\end{array}$ \\
\hline Crossbred & $3.1^{\mathrm{a}}$ & 0.8 & 3.5 & 0.9 & 3.4 & 0.6 \\
\hline Purebred & $4.2^{\mathrm{b}}$ & 0.5 & 3.5 & 1.1 & 3.2 & 0.8 \\
\hline
\end{tabular}

Crossbreds had higher live and carcass weight and also a higher dressing percentage (Tab. 6).

Table 6

Effect of genotype on carcass traits $(n=53)$ (Einfluss des Genotyps auf Schlachtkörpermerkmale $(n=53))$

\begin{tabular}{|c|c|c|c|c|c|c|c|c|}
\hline \multirow[b]{2}{*}{ Genotype } & \multicolumn{2}{|c|}{$\begin{array}{l}\text { Live weight } \\
\text { (kg) }\end{array}$} & \multicolumn{2}{|c|}{$\begin{array}{l}\text { Carcass weight, } \\
\text { warm (kg) }\end{array}$} & \multicolumn{2}{|c|}{$\begin{array}{l}\text { Carcass weight, } \\
\text { cold (kg) }\end{array}$} & \multicolumn{2}{|c|}{$\begin{array}{l}\text { Dressing } \\
\text { percentage (\%) }\end{array}$} \\
\hline & LSM & SE & LSM & SE & LSM & SE & LSM & SE \\
\hline Crossbred & $16.9^{\mathrm{a}}$ & 0.6 & 9.5 & 2.0 & $8.2^{\mathrm{a}}$ & 0.3 & $48.2^{\mathrm{a}}$ & 0.0 \\
\hline Purebred & $12.8^{\mathrm{b}}$ & 0.9 & 5.1 & 3.1 & $5.4^{\mathrm{b}}$ & 0.5 & $42.4^{\mathrm{b}}$ & 0.0 \\
\hline
\end{tabular}

Means with different letters for each trait differ significantly $(\mathrm{p}<0.05)$.

This finding also runs through the single weights of carcass parts; neck, oyster with shoulder, back, hind knuckle with gigot and breast were all significantly heavier in crossbreds (Tab. 7). Sex had a significant influence on all single weights besides back weight. Birth weight had a significant influence on oyster with shoulder, back and breast.

Table 7

Effect of genotype on meat quality traits $(n=53)$ (Einfluss des Genotyps auf Merkmale der Fleischqualität $(n=$ 53))

\begin{tabular}{|c|c|c|c|c|c|c|c|c|c|c|c|c|}
\hline \multirow[b]{2}{*}{ Genotype } & \multicolumn{2}{|l|}{$\begin{array}{l}\text { Neck } \\
(\mathrm{kg})\end{array}$} & \multicolumn{2}{|l|}{$\begin{array}{l}\text { Breast } \\
\text { (kg) }\end{array}$} & \multicolumn{2}{|c|}{$\begin{array}{l}\text { Shoulder } \\
(\mathrm{kg})\end{array}$} & \multicolumn{2}{|l|}{$\begin{array}{l}\text { Back } \\
(\mathrm{kg})\end{array}$} & \multicolumn{2}{|l|}{$\begin{array}{l}\text { Gigot } \\
(\mathrm{kg})\end{array}$} & \multicolumn{2}{|c|}{$\begin{array}{l}\text { Valuable } \\
\text { parts (\%) }\end{array}$} \\
\hline & LSM & SE & LSM & SE & LSM & SE & LSM & SE & LSM & SE & LSM & $\mathrm{SE}$ \\
\hline Crossbred & $0.7^{\mathrm{a}}$ & 0.0 & $1.6^{\mathrm{a}}$ & 0.1 & $1.6^{\mathrm{a}}$ & 0.1 & $1.5^{\mathrm{a}}$ & 0.1 & $2.4^{\mathrm{a}}$ & 0.1 & 48.5 & 0.0 \\
\hline Purebred & $0.5^{\mathrm{b}}$ & 0.0 & $1.0^{\mathrm{b}}$ & 0.1 & $1.1^{\mathrm{b}}$ & 0.1 & $0.9^{\mathrm{b}}$ & 0.1 & $1.7^{\mathrm{b}}$ & 0.2 & 47.9 & 0.0 \\
\hline
\end{tabular}

The longissimus muscle area was significantly larger for crossbreds (Tab. 8). No significant influence of sex or birth weight could be proven.

Table 8

Effect of genotype on longissimus muscle area $(\mathrm{n}=53)($ Einfluss des Genotyps auf die Rückenmuskelfläche $(\mathrm{n}=$ 53))

\begin{tabular}{lcccc}
\hline & \multicolumn{2}{c}{ Area, left $\left(\mathrm{cm}^{2}\right)$} & \multicolumn{2}{c}{ Area, right $\left(\mathrm{cm}^{2}\right)$} \\
Genotype & LSM & SE & LSM & SE \\
\hline Crossbred & $6.4^{\mathrm{a}}$ & 0.3 & $6.2^{\mathrm{a}}$ & 0.3 \\
Purebred & $4.5^{\mathrm{b}}$ & 0.4 & $4.3^{\mathrm{b}}$ & 0.4 \\
\hline Means with different letters for each trait differ significantly $(\mathrm{p}<0.05)$. & \multicolumn{2}{c}{}
\end{tabular}

Crossbreds had significantly longer gigot girth and gigot length than purebreds (Tab. 9). Back length was also longer but no significant differences could be proven. Birth weight had a significant influence on gigot girth and gigot length. Sex did not have any significant influence on carcass measurements. 
Table 9

Effect of genotype on back and gigot length, gigot girth (n = 53) (Einfluss des Genotyps auf Rücken- u. Keulenlänge sowie Keulenumfang ( $=53)$ )

\begin{tabular}{lllllll}
\hline & \multicolumn{2}{l}{ Back length $(\mathrm{cm})$} & \multicolumn{2}{l}{ Gigot girth $(\mathrm{cm})$} & \multicolumn{2}{l}{ Gigot length $(\mathrm{cm})$} \\
Genotype & LSM & SE & LSM & SE & LSM & SE \\
\hline Crossbred & 39.2 & 1.0 & $41.9^{\mathrm{a}}$ & 0.6 & $25.5^{\mathrm{a}}$ & 0.4 \\
Purebred & 37.5 & 1.7 & $36.8^{\mathrm{b}}$ & 1.0 & $23.4^{\mathrm{b}}$ & 0.6 \\
\hline
\end{tabular}

Means with different letters for each trait differ significantly $(\mathrm{p}<0.05)$.

No significant influences could be proven for meat quality (Tab. 10).

Table 10

Effect of genotype on meat quality ( $n=53$ resp. $n=36$ for lightness) (Einfluss des Genotyps auf die Fleischqualität ( $\mathrm{n}=53$ bzw. $\mathrm{n}=36$ für Fleischhelligkeit))

\begin{tabular}{|c|c|c|c|c|c|c|c|c|c|c|c|c|c|c|}
\hline \multirow[b]{2}{*}{ Genotype } & \multicolumn{2}{|c|}{$\mathrm{pH}_{45}$} & \multicolumn{2}{|c|}{$\mathrm{pH}_{24}$} & \multicolumn{2}{|c|}{$\mathrm{LF}_{24}$} & \multicolumn{2}{|c|}{$\begin{array}{c}\text { Shear value } \\
\left(\mathrm{kg} / \mathrm{cm}^{2}\right)\end{array}$} & \multicolumn{2}{|c|}{$\mathrm{L}^{*}$} & \multicolumn{2}{|c|}{$a^{*}$} & \multicolumn{2}{|c|}{$\mathrm{b}^{*}$} \\
\hline & LSM & $\mathrm{SE}$ & LSM & SE & LSM & SE & LSM & SE & LSM & SE & LSM & SE & LSM & SE \\
\hline Crossbred & 6.6 & 0.0 & 5.8 & 0.1 & 1.6 & 1.1 & 9.1 & 0.3 & 40.6 & 1.4 & 11.5 & 0.4 & 2.2 & 0.3 \\
\hline Purebred & 6.6 & 0.0 & 5.9 & 0.1 & 1.4 & 1.7 & 8.6 & 0.5 & 42.2 & 2.4 & 12.4 & 0.7 & 2.8 & 0.5 \\
\hline
\end{tabular}

\section{Discussion}

One aim of the present study was to investigate the relevance of birth weight as a parameter for vitality and survivability of kids. Factors with significant influence on the birth weight of kids were sex, genotype and age of doe. This is in agreement with studies of SINGH (1985), PANANDAM et al. (1992) and SCHRÖDER (1995) in case of sex and with SNELL (1996) in case of sex and age of doe.

Other than expected, type of birth had no influence on birth weight. This is in opposition to SINGH (1985) who found a significant effect of birth type on birth weight and a negative correlation between both. SINGH et al. (1990) and AWEMU et al. (1999) proofed a significant influence of birth type on survivability of kids. Besides rectal temperature 3 hours p.p., factors regarded as possible vitality parameters like time span from birth to first standing and colostrum intake were not influenced by birth weight. As second significant factor sex had an impact on rectal temperature 3 hours p.p. Nevertheless, all investigated kids had rectal temperatures in a very narrow range of $39.1^{\circ} \mathrm{C}$ to $39.5^{\circ} \mathrm{C}$. This is even narrower than in the study of KAULFUSS et al. (1999) where lambs that survived during the study period had rectal temperatures in the range of 39 to $41^{\circ} \mathrm{C}$. In the same study, $40 \%$ of lambs that died suffered of hypothermia of less than $39^{\circ} \mathrm{C}$. Hence, the authors conclude that rectal temperature is a trait which refers directly to the health status of lambs already in the first 24 hours of their life. Nevertheless, all possible vitality parameters besides birth weight proved to be very time intensive to determine. Time investment was not justified by the obtained results.

The average daily weight gain of kids in the present study was already in phase 1 lower than weight gains reported by other authors for a similar time span but meat type kids (SHERIDAN et al., 2003). During phase 2 all kids realised a very low weight gain; the available feed covered mainly their maintenance needs. Birth weight had a significant influence on daily weight gain during the period of landscape management. Kids with higher birth weight showed a slightly better weight gain during this period of restricted feeding. Also, genotype had a significant influence on weight gain during the restricted period. This is in accordance with LAES-FETTBACK and PETERS 
(1995) who found significant breed effects on daily weight gain during restricted feeding in a similar age class.

In the present study, birth weight had a significant effect on a few carcass parts (oyster with shoulder, back, breast) and also on gigot girth and gigot length. Therefore, higher birth weight in kids implies a high probability of a better carcass performance especially in some valuable parts. VILLETTE and THERIEZ (1981) found that the carcass of lambs exhibiting a low birth weight contained more fat and less bone. The chemical composition of the carcass as well as that of the body weight showed a higher fat content and lower water content. However, those results were not significant.

Still, in the present study the effect of the genotype on carcass performance was considerably higher than any other investigated effect. This was also true for longissimus muscle area which was in the same range as values of OMAN et al. (2000). OMAN et al. (2000) proofed genotype-differences in longissimus muscle area; Angora goats, a fibre goat like Cashmere, had significantly smaller longissimus muscle area than other investigated genotypes. RINGDORFER (2001) observed effects of genotype and sex on carcass value, carcass cuts and tissue composition in Boer and Boer-crossbred kids. DHANDA et al. (2003) could also proof an influence of the genotype on the muscle content of the carcass: Saanen $\mathrm{x}$ Angora-crossbreds had significant lower proportion than purebred Saanen, Boer and Feral goats or crossbreds between those. In the study of OMAN et al. (2000), Angora goats had lighter live and hot carcass weights than other genotypes when slaughtered at a given age. For carcass measurements, carcasses of Angora goats in the same study were shorter than those of other genotypes and also leg circumferences of purebred Angora goats were smaller than those of crossbred Boer x Spanish- and Spanish x Angora-goats.

Looking at carcass scoring, Cashmere kids got a significantly inferior score in meatiness in the present study than crossbreds. There were nearly no differences in fat cover of the carcass in- and outside. This finding might be an expression for the low meat performance of Cashmere type goats and their disposedness to higher fatpercentages in the body. JOHNSON (2000) observed that purebred Cashmere and Boer x Cashmere kid carcasses had more subcutaneous and intermuscular fat than carcasses of Boer x feral kids. DHANDA et al. (1999) observed a significantly greater subcutaneous fat thickness in chevon carcasses of Boer $x$ Angora-crossbreds than in other genotypes they investigated. In the study of OMAN et al. (2000) primal cuts from Angora carcasses were always the fattest or among the fattest. This applied to purebreds but also for Spanish x Angora-crossbreds.

No genotype-effect could be verified for meat quality. The $\mathrm{pH}$-values were in a range as reported by other authors (RINGDORFER, 2001; PRATIWI et al., 2004). Shear values in the present study were quite high with $9.1 \mathrm{~kg} / \mathrm{cm}^{2}$ (crossbreds) resp. 8.6 $\mathrm{kg} / \mathrm{cm}^{2}$ (purebreds). SEN et al. (2004) proved distinctively lower shear forces of 7.42 $\mathrm{kg} / \mathrm{cm}^{2}$ in goats and $3.74 \mathrm{~kg} / \mathrm{cm}^{2}$ in sheep with goats having also tougher meat in sensory evaluation. SWAN et al. (1998) found that meat of Cashmere goats showed higher tenderness than meat from other genotypes while there was no difference in shear force and sensory tenderness between Boer, Cashmere and crossbreds of the two breeds. STANKOV et al. (2002) as well as KADIM et al. (2004) could not proof any breed differences for shear force. With $\mathrm{a}^{*}$-values of 11.5 (crossbreds) resp. 12.4 (purebreds) the slaughtered kids had a dark muscle colour. Breed differences do not 
seem to play a role in meat colour of goats, no differences could be proofed. This is in accordance with other authors (STANKOV et al., 2002; KADIM et al., 2004).

Altogether, it could be shown that birth weight can be taken as a parameter for kid vitality. A reason for the minor evidence in this study might be that there have been only few death born and perished kids. Therefore, only the influence of birth weight on live animals could be investigated. It was proofed that the positive effect of a higher birth weight helps the animals to get over a period of scarce feed supply in better condition than animals with lower birth weight and that a higher birth weight will at last yield in better carcass performance. Other possible vitality parameters were rejected.

The results of the present study illustrate that goats of Cashmere type as fibre animals are not appropriate for landscape management. Otherwise, crossbred type animals with a meat, dairy and fibre component in their genotype showed to be a vital animal with acceptable efficiency also in harsh conditions and with an average meat and carcass performance.

\section{Acknowledgements}

The authors would like to thank Prof. Dr. W. H. Holtz for his discussion and for giving the opportunity to slaughter the experimental kids in the slaughter house of the Institute of Animal Breeding and Genetics, University of Göttingen. We would also like to thank Prof. Dr. H.-P. Piepho for his statistical advice.

\section{References}

AWEMU, E.M.; NWAKALOR, L.N.; ABUBAKAR, B.Y.:

Environmental influences on preweaning mortality and reproductive performance of Red Sokoto does. Small Rum. Res. 34 (1999), 161-165

DHANDA, J.S.; TAYLOR, D.G.; MURRAY, P.J.:

Part 2. Carcass composition and fatty acid profiles of adipose tissue of male goats: effects of genotype and liveweight at slaughter. Small Rum. Res. 59 (2003), 67-74

DHANDA, J.S.; TAYLOR, D.G.; MCCOSKER, J.E.; MURRAY, P.J.:

The influence of goat genotype on the production of capretto and chevon carcasses. 1. Growth and carcass characteristics. Meat Sci. 52 (1999), 355-361

EWG 2137/92:

Verordnung (EWG) Nr. 2137/92 des Rates vom 23. Juli 1992 über das gemeinschaftliche Handelsklassenschema für Schafschlachtkörper und die gemeinschaftliche Standardqualität frischer und gekühlter Schafschlachtkörper und zur Verlängerung der Geltungsdauer der Verordnung (EWG) Nr. 338/91 (1992)

EWG 461/93:

Verordnung (EWG) Nr. 461/93 der Kommission vom 26. Februar 1993 mit Bestimmungen zum gemeinschaftlichen Handelsklassenschema für Schlachtkörper von Schafen. (1993)

HAUMANN, P.:

Impact of calcareous grassland on grazing kids. In: PAPANASTASIS, V.P., FRAME, J., NASTIS, A.S. (Eds): Grasslands and woody plants in Europe, Grassland Science in Europe 4 (1999), 371-376

HAUMANN, P.:

Weiterentwicklung eines Selektionsprogramms für Landschaftspflegeziegen. Cuvillier Verlag, Göttingen, (2000)

JOHNSON, T.J.:

Evaluation of capretto carcasses from Boer cross and Cashmere goats in the Mediterranean climate of Western Australia. Proc. $7^{\text {th }}$ Int. Conf. on Goats, Tour, France. Int. Goats Assoc., Little Rock, (2000), 219

KADIM, I.T.; MAHGOUB, P.; AL-AJMI, D.S.; AL-MAQBALY, R.S.; AL-SAQRI, N.M.; RITCHIE, A.:

An evaluation of the growth, carcass and meat quality characteristics of Omani goat breeds. Meat Sci. 66 (2004), 203-210 
KAULFUSS, K.-H.; SCHENK, P.; SÜSS, R.:

Fiebermessen - Lämmer retten. Dt. Schafzucht 4 (1999), 96-98

KEEN, A.; ENGEL, B.:

Analysis of a mixed model for ordinal data by iterative reweighed REML. Statistica Neelandica $\mathbf{5 1}$ (1997), 129-144

LAES-FETTBACK, C.; PETERS, K.-J.:

A comparative study of performance of Egyptian goat breeds. II. Growth performance and productivity. Arch. Tierz., Dummerstorf 38 (1995), 563-575

MCCULLAGH, P.:

Regression models for ordinal date (with discussion). J. Roy. Statist. Soc. B. 42 (1980), 109-142

MCCULLAGH, P.; NELDER, J.A.:

Generalized linear models. $2^{\text {nd }}$ Ed., Chapman and Hall, London, (1989)

OMAN, J.S.; WALDRON, D.F.; GRIFFIN, D.B.; SAVELL, J.W.:

Carcass traits and retail display-life of chops from different goat breed types. J. Anim. Sci. 78 (2000), 1262-1266

PANANDAM, J.M.; MUKHERJEE, T.K.; HORST, P.:

Birth weight, growth, kid mortality and female reproduction of crosses between the Malaysian and German Fawn goats. Proc. V. International Conference on Goat, New Dehli, (1992), 613-622

PIEPHO, H.-P.:

Schwellenwertmodelle mit festen und zufälligen Effekten für Boniturdaten aus landwirtschaftlichen Versuchen. Informatik, Biometrie und Epidemiologie in Medizin und Biologie 28 (1997), 398-399

PIEPHO, H.-P.:

Ein SAS Makro zur Auswertung von geordneten kategorialen Daten nach dem Schwellenwertmodell mit festen und zufälligen Effekten. 2. Konferenz der SAS-Benutzer in Forschung und Entwicklung (KSFE), 26.2.-27.2.1998, Jena, 185-195

PRATIWI, N.M.W.; MURRAY, P.J.; TAYLOR, D.G.:

Meat quality of entire and castrated male Boer goats raised under Australian conditions and slaughtered at different weights: Physical characteristics, shear force values and eating quality profiles. Anim. Sci. 79 (2004), 213-219

RINGDORFER, F.:

Einfluss von Genotyp, Geschlecht und Endgewicht auf die Schlachtleistung von Ziegenkitzen. Arch. Tierz., Dummerstorf 44 (2001), 385-390

SCHÖN, L.

Schlachttierbeurteilung - Schlachtkörperbewertung. DLG-Verlag, Frankfurt/Main, (1961)

SCHEPER, J.; SCHOLZ, W.:

DLG-Schnittführung für die Zerlegung der Schlachtkörper von Rind, Kalb, Schwein und Schaf. DLGVerlag, Frankfurt/Main, (1985)

SCHRÖDER, C.:

Rassenspezifische Eignung von Kaschmir-, Buren- und Edelziegen zur Erstpflege von Sukzessionsflächen, Verlag Dr. Kovač, Hamburg, (1995)

SEIBERT, B.; GAULY, M.; ERHARDT, G.:

Productivity of different sheep breeds in extensive pasture management. Arch. Tierz., Dummerstorf 47 (2004) Special Issue, 142-152

SEN, A.R.; SANTRA, A.; KARIM, S.A.:

Carcass yield, composition and meat quality attributes of sheep and goat under semiarid conditions. Meat Sci. 66 (2004), 757-763

SHERIDAN, R.; HOFFMAN, L.C.; FERREIRA, A.V.:

Meat quality of Boer goat kids and Mutton Merino lambs. 1. Commercial yields and chemical composition. Anim. Sci. 76 (2003), 63-71

SINGH, C.S.P.

Frequency of kidding, type of birth and birth weight of Saanen kids. Indian vet. med. J. 9 (1985), 242244

SINGH, D.K.; MISHRA, H.R.; SINGH, C.S.P.:

Genetic and non-genetic factors affecting pre-weaning survivability in kids. Anim. Prod. 51 (1990), 559-564

SNELL, H.:

Aufzucht- und Milchleistung von Ziegen der Produktionsrichtungen Milch, Fleisch und Faser. Züchtungskunde 68 (1996), 398-409

STANKOV, Iv.K.; TODOROV, N.A.; MITEV, J.E.; MITEVA, Tch.M.:

Study on some qualitative features of meat from young goat of Bulgarian breeds and crossbreds of goats slaughtered at various ages. Asian-Australasian J. Anim. Sci. 15 (2002), 283-289 
SWAN, J.E.; ESGUERRA, C.M.; FAROUK, M.M.:

Some physical, chemical and sensory properties of chevon products from three New Zealand goat breeds. Small Rum. Res. 28 (1998), 273-280

VILETTE, Y.; THERIEZ, M.:

Influence du poids à la naissance sur les performances d’agneaux de boucherie. II. Composition corporelle et chimique d'agneaux abattus au même poids. Small Rum. Res. 39 (1981), 169-182

Received: 2006-03-28

Accepted: 2006-12-05

Author's addresses

Dr. PERA HEROLD*

Institute of Animal Production in the Tropics and Subtropics

University of Hohenheim

70593 STUTTGART, GERMANY

*Corresponding Author, E-Mail: pherold@uni-hohenheim.de

Dr. HINRICH SNELL

Research Centre for Animal Production and Technology

University of Göttingen

Universitätsstr. 7

49377 VECHTA, GERMANY

E-Mail: hinrich.snell@bmelv.bund.de

Prof. Dr. EZZAT S. TAWFIK

FB 11 - Organic Agricultural Sciences

University of Kassel

Steinstr. 19

37213 WITZENHAUSEN, GERMANY

E-Mail: estawfik@aol.com 